\title{
EFEKTIVITAS PENDEKATAN SAINTIFIK DENGAN MEDIA BOOKLET HIGHER ORDER THINKING TERHADAP HASIL BELAJAR BIOLOGI SISWA SMA DI KABUPATEN WAJO
}

\author{
Ahmad Yani ${ }^{1}$, Muhsyanur $^{2}$, Sahriah $^{3}$, Haerunnisa $^{4}$, Sri Salmawati ${ }^{5}$ \\ 1,2,3,4 STKIP Puangrimaggalatung Sengkang Jl. Sultan Hasanuddin No. 27 Sengkang \\ Sulawesi Selatan \\ 5. Program Studi Pendidikan Biologi IAIN Ambon \\ E-mail: ahyan_yani@yahoo.com
}

\begin{abstract}
Abstrak: Penelitian ini bertujuan untuk mengetahui keefektifan pendekatan saintifik dengan menggunakan media booklet Higher Order Thinking (HOT) terhadap hasil belajar. Penelitian ini dilaksanakan di SMA Negeri 2 di Kabupaten Wajo tahun ajaran 2016/2017. Teknik pengambilan menggunakan metode cluster random sampling, dengan rancangan penelitian true experimental design dengan pola posttest only control design. Data hasil belajar kognitif diperoleh dari hasil post-test, data aktivitas siswa diperoleh berdasarkan hasil penilaian observer dan data tanggapan siswa terhadap pembelajaran diperoleh melalui angket. Hasil penelitian menunjukkan bahwa kelas eksperimen memiliki hasil belajar lebih tinggi dari pada kelas kontrol. Ketuntasan klasikal yang dicapai kelas eksperimen sebesar 82,40\% sedangkan kelas kontrol sebesar $54,80 \%$. Presentase aktivitas siswa kelas eksperimen sebesar 78,50\% sedangkan kelas kontrol sebesar $67,30 \%$. Siswa memberikan tanggapan positif terhadap penerapan pendekatan saintifik dengan media booklet HOT dan penilaian positif terhadap booklet HOT. Pengujian signifikansi perbedaan dengan uji $t$ menunjukkan bahwa $t_{\text {hitung }} \geq t_{\text {tabel }}$ berarti terdapat perbedaan yang signifikan antara kedua kelompok. Dapat disimpulkan bahwa pendekatan saintifik berbantuan booklet HOT efektif terhadap pencapaian hasil belajar.
\end{abstract}

\section{Kata Kunci: Pendekatan Saintifik, Higher Order Thinking, Hasil Belajar}

Pendidikan di Indonesia dihadapkan pada suatu permasalahan yaitu rendahnya mutu pendidikan. Walaupun berbagai upaya yang telah dilakukan, namun hingga kini mutu pendidikan belum menunjukkan peningkatan yang berarti baik pada jenjang pendidikan dasar dan menengahm maupun pada jenjang perguruan tinggi (Wenno, 2010). Hasil PISA pertama pada tahun 2003 kemampuan literasi sains siswa Indonesia berada pada urutan 38 dari 40 peserta, tahun 2006 peringkat Indonesia berada pada urutan 50 dari 57 negara, tahun 2009 Indonesia berada pada peringkat 66 dari 67 negara peserta, pada tahun 2012 berada pada peringkat 64 dari 65 negara peserta terakhir pada tahun 2015 menempati peringkat 69 dari 76 negara peserta (OECD, 2005; OECD, 2007; OECD,

BIOLOGI SEL (VOL 7 NO 1 EDISI JAN-JUL 2018 ISSN 2252-858X/E-ISSN 2541-1225) PAGE 1 
2010; OECD, 2012; BBC, 2015). Selain itu, menurut The Political and Economic Risk Consultancy (PERC) yang merupakan lembaga konsultan dari Hongkong menyatakan kualitas pendidikan di Indonesia sangat rendah, Indonesia berada di peringkat ke12 dari negara-negara di Asia (Noviar \& Hastuti, 2015).

Tantangan masa depan menuntut pembelajaran, khususnya pembelajaran sains lebih mengembangkan higher order of thinking (HOT). Ironisnya, pembelajaran pada kenyataannya masih banyak yang semata berorientasi pada upaya mengembangkan dan menguji daya ingat peserta didik sehingga kemampuan berfikir peserta didik direduksi dan sekedar dipahami sebagai kemampuan untuk mengingat (Tan \& Halili, 2015). Selain itu, hal tersebut juga berakibat peserta didik terhambat dan tidak berdaya menghadapi masalah-masalah yang menuntut pemikiran dan pemecahan masalah secara kreatif (Bahr, 2010). Pembelajaran biologi tidak hanya sekedar menghafal materi, memahami konsep, dan transfer ilmu dari guru kepada siswa. Namun pembelajaran biologi harus memperhatikan pengembangan kemampuan berpikir siswa seperti kemampuan menalar, karena ilmu biologi sangat terkait dengan kehidupan nyata. Hal tersebut sejalan dengan assessment framework dalam TIMSS 2011 bahwa pengembangan dimensi kognitif mencakup tiga ranah kemampuan yaitu pengetahuan (knowing), penerapan (applying), dan penalaran (reasoning).

Kemampuan penalaran merupakan kemampuan berpikir tingkat tinggi (Higher Order Thinking Skill/HOTS) yang harus dimiliki dan dikembangkan oleh siswa. Dengan demikian pembelajaran harus mampu melatih kemampuan berpikir tingkat tinggi siswa sehingga menumbuhkan daya nalar yang baik. Menurut Paul (1990) pentingnya kehidupan anak dilatih untuk berpikir tingkat tinggi, yaitu anak bisa memahami informasi, berpikir yang berkualitas, mencapai hasil akhir berkualitas sehingga menjadi mandiri. Semakin baik kemampuan berpikir siswa akan berdampak baik tehadap hasil belajar siswa.

Perubahan kurikulum merupakan salah satu upaya pemerintah untuk meningkatkan kualitas pembelajaran yaitu melalui perubahan kurikulum dari kurikulum KTSP menjadi kurikulum 2013. Penerapan kurikulum ditandai dengan perubahan pendekatan pembelajaran saintifik, guru memiliki kebebasan berinovasi dan memilih model pembelajaran yang diterapkan di kelas untuk menciptakan pembelajaran yang berpusat pada siswa serta, menggunakan sumber dan media pembelajaran untuk meningkatkan kualitas pembelajaran khususnya pada pembelajaran Biologi. Tuntutan kurikulum saat ini mengharapkan siswa memiliki kecakapan kognitif, kemampuan dalam dunia nyata, dan berakhlak mulia serta lebih aktif dalam proses pembelajaran. Dalam pembelajaran nantinya guru sebagai sumber informasi utama akan berubah menjadi pembelajar yang lebih ideal dengan permasalahan yang real dan berorientasi pada siswa sehingga siswa dapat mengkonstruksi sendiri pengetahuannya dan terlibat aktif dalam mencari informasi (Insyasiska, Zubaidah, \& Susilo, 2015). Guru dalam 
konteks pendidikan mempunyai peranan yang besar sehingga menuntut guru mempunyai strategi dan kreativitas dalam proses belajar mengajar. Tuntutan dari kurikulum adalah siswa dan guru harus lebih aktif (Pratiwi, Suwono, \& Handayani, 2013). Siswa harus aktif dalam kegiatan belajar sedangkan guru harus aktif dalam menyiapkan perangkat pembelajaran dan memotivasi siswa untuk lebih giat belajar agar pembelajaran lebih efektif.

Pembelajaran biologi yang berpusat pada siswa memberikan kesempatan siswa untuk berpartisipasi aktif dalam pembelajaran sehingga mampu meningkatkan kemampuan berfikir dan kreativitas serta kompetensi siswa. Pembelajaran biologi yang berpusat pada siswa dimaksudkan untuk melibatkan siswa dalam mengkonstruksi sendiri pengetahuannya sehingga siswa lebih dominan dalam pembelajaran. Hal tersebut dapat mengembangkan pengetahuan, keterampilan dan sikap percaya diri siswa. Selain itu, proses pembelajaran biologi harus berdasarkan data dan fakta ilmiah agar diperoleh suatu pembelajaran yang bermakna. Permasalahan pembelajaran sains (termasuk fisika, biologi, dan kimia) antara yaitu kreativitas, bahan ajar/bahan kajian. Hal tersebut sesuai dengan teori bahwa pembelajaran dengan menggunakan pendekatan saintifik adalah pembelajaran yang menekankan pada pemberian pengalaman secara langsung baik menggunakan observasi, eksperimen, maupun cara lainnya sehingga realitas yang akan berbicara sebagai informasi atau data yang diperoleh selain valid juga dapat dipertanggungjawabkan (Agus Sujarwanta, 2012:75).

Berdasarkan hasil observasi di SMA Negeri 2 Sengkang Kabupaten Wajo, pembelajaran biologi masih bergantung pada penjelasan guru. Pola pembelajaran di kelas selama ini sering menggunakan metode ceramah, presentasi dan guru lebih berperan aktif dalam pembelajaran. Karena keterlibatan siswa kurang, sehingga pembelajaran menjadi pasif dan siswa kurang kritis dalam menerima pembelajaran. Wawancara dengan guru menunjukkan kemampuan berpikir tingkat tinggi dalam mengerjakan soal C4-C6 masih taraf sedang, karena siswa kurang dilatih untuk berfikir tingkat tinggi. Belum adanya sumber belajar yang melatih kemampuan berpikir tingkat tinggi siswa, menjadi salah satu faktor penyebab pembelajaran kurang mandiri. Berdasarakan hasil observasi, faktor-faktor tersebut diduga mempengaruhi persentase ketuntasan belajar pada materi plantae yang dicapai pada tahun ajaran 2014/2015 hanya mencapai $60 \%$. Tingkat hasil belajar tidak hanya dipengaruhi oleh potensi siswa tetapi juga pendekatan dan sumber pembelajaran yang mendukung serta relevan. Tingkat berpikir siswa tidak dapat lepas dari pengaruh pendekatan, strategi, model dan sumber belajar yang digunakan oleh guru. Pendekatan saintifik merupakan suatu pendekatan berpikir dan berbuat yang diawali dengan mengamati (Observing) dan menanya (Questioning) sampai kemudian mereka berupaya untuk mengumpulkan data, mencoba (Experimen-ting), menalar/mengolah informasi (Associating), dan akhirnya dapat mengkomunikasikan (Communicating) hasil. Melalui salah satu kegiatan tersebut, 
seperti kegiatan mengamati gambar siswa dapat secara langsung menceritakan kondisi sebagaimana yang dituntut dalam Kompetensi Dasar (KD) dan indikator, serta mata pelajaran apa saja yang dapat dipadukan dengan media yang tersedia (Pemendikbud, 2013). Kegiatan-kegiatan tersebut menuntut siswa untuk aktif dalam pembelajaran sehingga pembelajaran menjadi lebih bermakna. Pendekatan saintifik berpusat pada student center dan menekankan partisipasi aktif siswa terhadap sumber belajar melalui 5 langkah belajar. Langkah menanya pada pendekatan saintifik sangat diperlukan untuk mengembangkan kemampuan berpikir siswa melalui pemberian beberapa pertanyaan yang bervariasi berdasarkan pada taksonomi kognitif Bloom. Merujuk teori konstruktivis, siswa dalam belajar dipandang sebagai subyek yang harus membangun pengetahuannya sendiri secara aktif salah satunya melalui bertanya. Menurut Piaget, pengetahuan tidak dapat ditransfer dari otak guru yang dianggap tahu bila siswa tidak mengolah dan membentuknya sendiri (Suparno, 2001). Oleh karena itu, perlu memadukan pendekatan yang tepat dan sumber belajar yang relevan guna menunjang kemampuan berfikir sehingga siswa dapat mengasosiasi dan mengakomodasi skema yang telah dimilikinya.

Booklet merupakan salah satu jenis sumber belajar by design. Booklet atau brosur dapat digunakan sebagai media pembelajaran selama sajiannya diturunkan dari kompetensi dasar yang harus dikuasai oleh siswa, agar tidak terlalu banyak kontent didesain hanya memuat satu kompetensi dasar saja. Gambar, grafik organizer seperti diagram v, diagram fish bone, tabel, variasi soal-soal, dan materi yang terdapat dalam Booklet Plantae HOTS mampu mendukung pengembangan kemampuan berpikir tingkat tinggi siswa. Hal tersebut didasarkan pada hasil penelitian Hapsari (2012), ada pengaruh secara signifikan penggunaan diagram $\mathrm{V}$ (Vee) dalam pembelajaran biologi terhadap kemampuan berpikir kritis siswa. Berdasarkan penelitian Lewy (2009), pemberian variasi soal berpikir tingkat tinggi memiliki potensial efek terhadap kemampuan berpikir siswa serta dapat digunakan untuk mengukur sejauh mana tingkat berpikir siswa. Materi plantae merupakan materi yang diajarkan pada kelas X Semester 2 sesuai kurikulum 2013. Ruang lingkup materi plantae sangatlah berkaitan dengan lingkungan kehidupan siswa sehingga penting untuk diberikan kepada siswa. Seringkali materi ini dianggap tidak terlalu penting karena mudah dipelajari. Namun, berdasarkan hasil survey Howell et al. (2012) masih banyak siswa tidak paham tentang konsep-konsep yang dianggap penting oleh pengajar, salah satunya yaitu terhadap materi ekologi. Hal tersebut diperkuat melalui hasil observasi di SMA Negeri 2 Sengkang terhadap hasil belajar pada materi plantae tahun 2015/2016 belum memuaskan, hanya mencapai $50 \%$. Berdasarkan uraian permasalahan tersebut, tujuan dari penelitian ini yaitu untuk menganalisis efektivitas pendekatan saintifik dengan Media Booklet Higher Order Thinking Skill terhadap Hasil Belajar, mendeskripsikan tanggapan siswa terhadap 
pembelajaran dengan menggunakan pendekatan saintifik dan renspon siswa terhadap media pembelajaran booklet HOT.

\section{METODE PENELITIAN}

Penelitian ini merupakan quasi experiment dengan menggunakan desing "true esprimental design" yaitu posttest only control design dapat dilihat Tabel 1.

Tabel 1. Rancangan Penelitian Non Equivalent Pretest-posttest Control Group Design

\begin{tabular}{lll} 
Kelas & Perlakuan & Post-tes \\
\hline Ekspriment & $\begin{array}{l}\text { Diterapkan pendekatan saintifik dengan media } \\
\text { booklet }\end{array}$ & Tes evaluasi \\
\hline Kontrol & Diterapkan pembelajaran konvensional & Tes evaluasi
\end{tabular}

Populasi dari penelitian ini yaitu siswa kelas X MIA 1 dan X MIA 2 SMA Negeri 2 Sengkang Kab. Wajo tahun pelajaran 2015/2016. Teknik pengambilan sampel dilakukan denggan teknik simple random sampling, terdiri atas satu kelas kontrol dan satu kelas eksprimen masing-masing terdiri atas 33 siswa. Kelas eksprimen diberikan treatment berupa pembelajaran dengan menggunakan pendekatan saintifik menggunakan media booklet HOT, sedangkan kelas kontrol diberikan pembelajaran tanpa menggunakan media dan konvensional. Penelitian ini terdiri atas satu variabel bebas yaitu pembelajaran dengan menerapkan pendekatan saintifik menggunakan media booklet HOT dan variabel terikat yaitu hasil belajar siswa. Teknik pengambilan data dilakukan dengan metode tes dan penyebaran angket. Nilai tes yang diperoleh melalui post-test. Instrumen yang digunakan dalam penelitian ini terdiri atas perangkat pembelajaran (silabus, RPP, dan booklet), tes hasil belajar kognitif, angket tanggapan siswa terhadap pembelajaran dengan pendekatan saintifik dengan media booklet HOT dan tanggapan siswa terhadap booklet HOT. Analisis data yang digunakan yaitu uji normalitas, homogenitas, uji kesamaan dua rata-rata, uji ketuntasan pembelajaran.

\section{HASIL DAN PEMBAHASAN}

Hasil penelitian meliputi hasil belajar siswa, tanggapan siswa terhadap penerapan pendekatan saintifik dengan media booklet dan tanggapan siswa terhadap booklet HOT. Berdasarkan hasil dan analisis data penelitian yang telah dilakukan pada kelas sampel yaitu kelas MIA-2 sebagai kelas eksprimen dan kelas X MIA-1 sebagai kelas kontrol. Data hasil belajar (post-test) kognitif siswa dapat dilihat pada Tabel. 2. Tabel 2. Hasil Belajar Kognitif Siswa Kelas Ekprimen dan Kelas Kontrol

\begin{tabular}{lll}
\hline Deskripsi & Kelas Eksprimen & Kelas Kontrol \\
\hline Banyaknya siswa & 33 & 32 \\
Rata-rata & 73 & 61 \\
Nilai tertinggi & 87 & 73 \\
Nilai terendah & 57 & 40 \\
Ketuntasan & $82,4 \%$ & $54,8 \%$ \\
\hline
\end{tabular}


Pada Tabel 2. Terlihat bahwa rata-rata hasil belajar kognitif kelas eksprimen lebih tinggi dari kelas kontrol. Untuk membuktifikan apakah tes hasil belajar kognitif kedua kelas sampel berbeda secara saignifikan atau tidak, maka dilakukan uji hipotesis. Sebelum dilakukan uji hipotesis terlebih dahulu dilakukan uji normalitas dan uji homogenitas. Hasil uji normalitas dan homogenitas tes akhir kelas sampel dapat dilihat pada Tabel 3 dan Tabel 4. Berdasarkan uji normalitas dan homogenitas kedua sampel terdistibusi normal dan mempunyai varians yang homogen. Oleh karena itu, untuk menguji hipotesis digunakan uji t dan data hasil uji hipotesis disajikan pada Gambar 1.

Tabel 2. Hasil Uji Normalitas Post-tes Kelas Sampel

\begin{tabular}{lllllll}
\hline Kelas & $\mathbf{N}$ & $\boldsymbol{\alpha}$ & $\boldsymbol{X}_{\text {hitung }}^{2}$ & $\boldsymbol{X}_{\text {tabel }}^{2}$ & Analisis & Distribusi \\
\hline Eksprimen & 33 & 0.05 & 8.376 & 11.07 & $\boldsymbol{X}_{\text {hitung }}^{2}<\boldsymbol{X}_{\text {tabel }}^{2}$ & Normal \\
Kontrol & 32 & 0.05 & 3.761 & 11.07 & $\boldsymbol{X}_{\text {hitung }}^{2}<\boldsymbol{X}_{\text {tabel }}^{2}$ & Normal \\
\hline
\end{tabular}

Tabel 3. Hasil Uji Homogenitas Post-tes Kelas Sampel

\begin{tabular}{|c|c|c|c|c|c|}
\hline Kelas & $\mathbf{S}^{2}$ & $F_{h}$ & $\mathbf{F}_{\mathbf{t}}$ & Analisis & Distribusi \\
\hline Eksprimen & 50.946 & 3.287 & 3.841 & $\mathrm{~F}_{\mathrm{b}}<\mathrm{F}_{\text {tahol }}$ & Homogen \\
\hline Kontrol & 97.65 & 3.281 & 3.841 & & \\
\hline
\end{tabular}

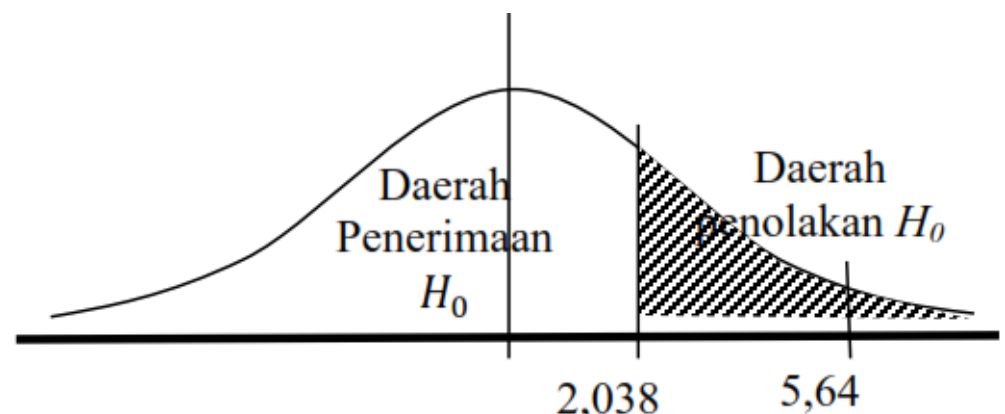

Gambar 1. Uji Hipotesis Pihak Kanan

Berdasarkan pada Gambar 1. diperoleh $t^{\prime} \geq 2,038$ dengan $\mathrm{dk}=n_{i}-1$ dan peluang $(1-\alpha) ; \alpha 5 \%$ sehingga $\mathrm{H}_{\mathrm{o}}$ ditolak, artinya rata-rata nilai evaluasi kelompok eksprimen lebih baik dari kelompok kontrol. Sedangkan hipotesis ketuntasan hasil belajar secara individual dengan menggunakan statistik $\mathrm{z}$ diperoleh hasil perhitungan $z=0,502519>-z_{0,5-\alpha \text { dimana } z_{0,5}-\alpha}$ didapat dari daftar normal baku dengan $\alpha=0,05$ diperoleh $z_{0,45}=1,64$, sehingga $H_{0}$ diterima. Artinya presentase siswa yang tuntas individual dengan nilai KKM 75 lebih dari atau sama dengan $75 \%$. Hasil analisis aktifitas siswa pada saat proses pembelajaran berlangsung dapat dilihat pada Tabel 4 . 
Tabel 4. Presentase Aktifitas Siswa pada Saat Pembelajaran Berlangsung

\begin{tabular}{|c|c|c|c|c|c|}
\hline \multirow[b]{2}{*}{$\begin{array}{l}\text { No } \\
\text {. }\end{array}$} & \multirow[b]{2}{*}{ Aspek Yang Diamati } & \multicolumn{2}{|l|}{ Eksprimen } & \multicolumn{2}{|l|}{ Kontrol } \\
\hline & & Presentase & $\begin{array}{l}\text { Rata- } \\
\text { rata }\end{array}$ & Presentase & $\begin{array}{l}\text { Rata- } \\
\text { rata }\end{array}$ \\
\hline $\mathrm{A}$ & $\begin{array}{l}\text { Aktivitas umum } \\
\text { Keaktifan siswa dalam berdiskusi } \\
\text { Siswa dalam mengerjakan tugas atau lembar } \\
\text { diskusi }\end{array}$ & $\begin{array}{l}91,60 \\
75\end{array}$ & 83,33 & $\begin{array}{l}75 \\
50\end{array}$ & 62,5 \\
\hline B & $\begin{array}{l}\text { Aktivitas berpikir kritis } \\
\text { Keaktifan siswa bertanya dalam memperoleh } \\
\text { informasi dan pemahaman saat berdiskusi } \\
\text { Keaktifan siswa menjawab pertanyaan dan } \\
\text { mengungkapkan ide } \\
\text { Keaktifan siswa mencari tahu tentang } \\
\text { pembelajaran melalui kegiatan pengamatan, } \\
\text { membaca, dll. } \\
\text { Keaktifan siswa mempresentasikan hasil } \\
\text { pekerjaan } \\
\text { Keaktifan siswa melakukan evaluasi dengan } \\
\text { cara memberikan tanggapan dan sanggahan } \\
\text { kepada temannya }\end{array}$ & $\begin{array}{l}58,30 \\
50 \\
100 \\
50 \\
50\end{array}$ & 61,6 & $\begin{array}{l}41,60 \\
25 \\
25\end{array}$ & 31,1 \\
\hline $\mathrm{C}$ & $\begin{array}{l}\text { Aktivitas berpikir kreatif } \\
\text { siswa menghubungkan konsep materi dalam } \\
\text { bentuk skema, gambar, diagram atau tabel } \\
\text { Keaktifan siswa mendesain percobaan melalui } \\
\text { kegiatan merumuskan masalah, tujuan, } \\
\text { hipotesis dan langkah kerja }\end{array}$ & $\begin{array}{l}41,60 \\
75\end{array}$ & 58,3 & - & \\
\hline $\mathrm{D}$ & $\begin{array}{l}\text { Aktivitas berpikir pemecahan masalah } \\
\text { Keaktifan siswa menghubungkan sebab akibat } \\
\text { dari suatu permasalahan. } \\
\text { Keaktifan siswa dalam memberikan solusi } \\
\text { dari suatu permasalahan }\end{array}$ & $\begin{array}{l}25 \\
37.50\end{array}$ & 31,25 & - & \\
\hline
\end{tabular}

Data pada Tabel 4. menunjukkan bahwa siswa menanggapi secara positif terhadap pembelajaran menggunakan pendekatan saintifik dengan media booklet, presentase yang diperoleh sebesar 92\%, sedangkan tanggapan siswa terhadap booklet HOT yaitu 94\% menaggapi positif dari segi kemudahan dalam memahami isi, ilustrasi dan kejelasan materi serta penggunaan bahasa. Berdasarkan data hasil penelitian yang tertera pada Tabel 1 tentang penerapan pendekatan saintifik dengan menggunakan booklet HOT efektif digunakan untuk meningkatkan hasil belajar siswa kelas X MIA di SMA Negeri 2 Sengkang Kabupaten Wajo. Pada Tabel 1, terlihat bahwa rata-rata hasil belajar siswa pada kelas eksprimen lebih tinggi dari kelas pada kelas kontrol. Selain itu, penerapan pendekatan saintifik dengan menggunakan media booklet HOT pada materi Plantae dikatakan efektif karena ketuntasan belajar siswa kelas eksprimen tergolong 
tinggi $(82,4 \%)$. Hal ini disebabkan karena pendekatan saintifik menekankan pada proses ilmiah yang dilakukaan dalam pada saat pembelajaran yaitu mengamati, menanya, mengumpulkan informasi, mengasosikan (mengolah informasi) dan mengomunikasikan (5M). Pencapain hasil belajar biologi siswa tidak terlepas dari hakekat pembelajaran pendekatan santifik, bahwa dalam saintifik siswa menemukan sendiri konsep-konsep, yang dipelajari. Menurut Marjan, Arnyana, \& Setiawan (2014) secara teoritis, pembelajaran pendekatan saintifik sangat memposisikan siswa sebagai pusat dalam pembelajaran (student centered), sehingga memberikan peluang pada peningkatan hasil belajar, pandangan paham konstruktivisme tentang pembelajaran bahwa, keterlibatan aktif siswa dalam pembelajaran memiliki peran yang penting dalam mengkonstruksi pemahaman dalam pikirannya.

Hasil uji hipotesis diperoleh th $>\mathrm{tt}$, data ini menunjukkan bahwa hasil belajar kognitif siswa kelas eksperimen lebih tinggi secara signifikan dari kelas kontrol, artinya penerapan pendekatan saintifik dengan menggunakan media booklet HOT efektif terhadap hasil belajar siswa kelas X MIA SMA Negeri 2 Sengkang Kabupaten Wajo. Hal ini sejalan dengan hasil penelitian melalui penerapan pendekatan saintifik berpengaruh positif terhadap hasil belajar kognitif dan dapat meningkatkan ketuntasan klasikal berdasarkan standar yang ditetapkan (Machin, 2013).

Hasil analisis aktivitas siswa pada saat proses pembelajaran berlangsung berada pada kategori tinggi, hal ini terlihat hasil observasi aktivitas siswa melalui aktifitas umum dalam pembelajaran dan proses berfikir tingkat tinggi (HOT) yaitu berfikir kritis, berfikir kreatif, dan befikir dalam pemecahan masalah. Terlihat perbedaan yang saignifikan aktifitas siswa kelas eksprimen dan kelas kontrol pada aspek HOT. Hal ini disebabkan karena media yang digunakan pada kelas eksprimen dirancang untuk melatih kemampuan berfikir siswa yaitu berfikir kritis, berfikir kreatif dan pemecahan masalah yang disajikan pada booklet materi Plantae. Booklet dikembangkan berdasarkan indikator kemampuan berfikir tingkat tinggi dan disusun berdasarkan prosedur pendekatan saintifik. Beberapa hasil penelitian menyatakan bahwa pembelajaran dengan menggunakan pendekatan saintifik efektif dalam meningkatkan kemampuan pemecahan masalah siswa (Anwar \& Lestari, 2016) dan meningkatkan keterampilan proses sains (Paulo \& Cruz, 2015). Menurut Jensen \& Lawson (2011) dampak positif yang dapat diperoleh oleh peserta didik dalam proses belajar mengajar yang mengimplementasikan pendekatan saintifik adalah terciptanya sistem pembelajaran yang dapat menghadirkan suasana menyenangkan serta kreatifitas tinggi yang mutlak diperlukan untuk meningkatkan motivasi belajar yang besar pengaruhnya terhadap hasil belajar siswa (Yerimadesi, Putra, \& Ririanti, 2017).

Proses pembelajaran yang dilakukan mendapat respon positif dari mahasiswa dan begitu juga dengan media yang digunakan. Media booklet yang dikembangkan telah melalui proses penelitian pengembangan $(\mathrm{R} \& \mathrm{D})$ dalam bidang pendidikan. Booklet 
yang dikembangkan dirancangan berbasis HOT dan dikembangkan berdasarkan alur pembelajaran saintifik.

Adapun tahapan tersebut yaitu: tahap stimulation, siswa diminta untuk mengamati gambar atau tabel yang disajikan pada pada booklet, sehingga siswa menjadi terangsang dan termotivasi untuk mempelajari materi yang akan dipelajari. Tahap ini merupa kan tahap yang berfungsi untuk menyediakan kondisi interaksi belajar yang dapat me nyumbangkan dan membantu siswa dalam mengeksplorasi bahan (Hosnan, 2014).

Tahap problem statemen (identifikasi masalah), melalui modul dan bimbingan guru siswa mengidentikasi permasalahan-permasalahan yang didapatkan pada tahap stimulation, kemudian merumuskan dan menuliskan hipotesis awal pada lembaran yang disediakan pada booklet. Pada kelas eksperimen umumnya siswa dapat menuliskan beberapa masalah yang ditemuinya dengan mempelajari modul bagian stimulation dan menuliskan hipotesis awal pada kolom yang telah disediakan pada modul. Tahap ini berlangsung lebih terarah, walaupun masih ada beberapa siswa yang belum mengisi dengan benar.

Tahap data collection (pengumpulan data), siswa menggali dan mengumpulkan informasi dengan berbagai cara yaitu, melakukan pecobaan/praktikum, mengamati objek/kejadian dan membaca sumber lain untuk membuktikan hipotesis yang sudah dituliskannya pada tahap problem statement. Berdasarkan pengamatan siswa melakukan percobaan dengan baik dan teliti serta menuliskan data yang diperoleh pada lembar pengamatan yang disediakan. Kegiatan ini membuat siswa aktif dan bersemangat, karena siswa memperoleh pengalaman belajar secara langsung, sehingga membuat pembelajaran menjadi bermakna dan bertahan lama dipikiran siswa. Pada tahap ini siswa bereksplorasi dengan cara berseksperimen (praktikum) dan mencermati literatur yang terdapat pada modul untuk membuktikan kebenaran dari hipotesis yang telah dibuat. Hal ini sesuai dengan yang dikemukakan (Hosnan, 2014), bahwa tahap data collection merupakan tahap eksplorasi, guru memberikan kesempatan kepada para siswa untuk mengumpulkan informasi yang relevan sebanyak-banyaknya untuk membuktikan benar atau tidaknya hipotesis awal.

Tahap data processing (pengolahan data), merupakan tahap pengkodean (coding/kategorisasi) yang berfungsi sebagai pembentukan konsep dan generalisasi (Hosnan, 2014). Pada tahap ini siswa pada kelas eksperimen mengerjakan soal-soal. Pada tahap ini hanya sedikit siswa yang kesulitan dalam menjawab soal. Hal ini berbanding terbalik dengan kelas kontrol, siswa masih kesulitan dalam menjawab soal, sehingga sering meminta penjelasan lebih lanjut dari guru. Hal ini terjadi kemungkinan karena pada kelas kontrol belum tersedia soal seperti pada modul, sehingga siswa tidak dapat dituntun dengan baik untuk menemukan konsep atau informasi baru. 
Tahap verification (pembuktian), siswa memeriksa secara cermat untuk membuktikan benar atau tidaknya hipotesis yang ditetapkan dengan temuan alternatif, dihubungkan dengan hasil data yang telah diolah (Permendikbud no 59 tahun 2014). Pada kelas eksperimen siswa menuliskan kembali hipotesis awal dan membuktikan kebenarannya berdasarkan informasi yang sudah diperoleh pada tahap data collection dan data processing. Pada tahap ini guru mengkonfirmasi jawaban siswa. Berdasarkan pengamatan pada tahap verification ini, siswa kelas eksperimen dapat membuktikan hipotesis awal yang telah ditulisnya pada tahap problem statement dibandingkan dengan kelas kontrol. Pada kelas eksperimen siswa berpastisipasi secara aktif dalam menyampaikan hasil diskusi mereka, sedangkan kelas kontrol siswa kurang aktif. Hal ini terjadi karena tahapan-tahapan sebelumnya (stimulation, problem statement, data collection, data processing) pada kelas kontrol belum menuntun siswa untuk aktif dalam pembelajaran. Tahap terakhir yaitu tahap generalization (menarik kesimpulan), merupakan tahap merumuskan prinsip-prinsip dan menarik kesimpulan dari hasil verification. Pada tahap ini siswa kelas eksperimen menuliskan kesimpulan yang telah diperoleh pada lembaran yang disediakan di modul. Siswa juga diminta untuk menyampaika kesimpulan yang diperoleh secara lisan di kelas. Melalui tahap generalization guru memberikan penguatan dari konsep yang telah didapat oleh siswa. Tahapan-tahapan inilah seharusnya dilalui oleh siswa untuk membangun pemahaman konsep dan kemampuan berfikir siswa. Hal ini sejalan yang dikemukan oleh Harmsen (2007) bahwa belajar yang sesungguhnya tidak menerima begitu saja konsep yang sudah jadi, akan tetapi siswa harus memahami bagaimana dan dari mana konsep tersebut terbentuk melalui kegiatan mencoba dan menemukan. Karena belajar berkonotasi pada aktivitas siswa, sedangkan aktivitas individu dapat dipengaruhi oleh kondisiemosional, maka sepantasnya suasana pembelajaran yang kondusif dalam keadaan nyaman dan menyenangkan (Yerimadesi, Putra, \& Ririanti, 2017).

Selain menerapkan pendekatan, metode dan model pembelajaran hal lain yang dapat mempengaruhi hasil belajar yaitu media pembelajaran. Sebagaimanan yang telah digunakan dalam penelitian ini yaitu booklet yang dapat merangsang siswa untuk berfikir tingkat tinggi (HOT) dan disusun berdasarkan langkah-langkah saintifik dengan menyajikan permasalahan. Setelah dilakukan validasi ahli materi dan pengembangan media booklet digunakan dalam pembelajaran. Siswa memberikan tanggapan positif terhadap booklet yang digunakan dalam pembelajaran karena disusun secara sistematis, mudah dipahami, dan merangsang untuk melakukan proses berfikir sehingga baik digunakan sebagai media pembelajaran. Hal ini sejalan dengan hasil penelitian media pembelajaran booklet efektif sebagai media penyampaian informasi dapat disesuaikan dengan karakteristik pembacanya dan didesain dengan ilustasi yang menarik serta lebih spesifik. 


\section{KESIMPULAN}

Berdasarkan hasil penelitian dan analisis data disimpulkan bahwan penerapan pendekatan saintifik dengan menggunakan media booklet HOT efektif terhadap pencapaian hasil belajar berdasarkan nilai ketuntasan minimal 75 dan meningkatkan aktifitas siswa serta melatih kemampuan HOT. Hasil belajar siswa yang diajar melalui penerapan pendekatan saintifik menggunakan media booklet HOT lebih tinggi secara saignifikan dari pada hasil belajar kognitif siswa menggunakan pembelajaran konvensional.

\section{SARAN}

Penggunaan booklet HOT dengan memadukannya dengan pendekatan saintifik sangat baik dalam meningkatkan hasil belajar cognitif dan aktifitas siswa, sehingga layak untuk digunakan oleh guru dalam mengajar, khususnya pada matapelajaran biologi

\section{REFERENSI}

Anwar, \& Lestari, H. P. (2016). Effectiveness Of The Application Of Think Pairs Share (TPS) and Spontaneous Group Discussion ( SGD ) Learning Models Combined With Scientific Approach In Terms Of Problem Solving And Self-Confidence In Class X MIA Student At Man 1 Yogyakarta, (2), 1-12.

Bahr, N. (2010). Thinking Critically about Critical Thinking in Higher Education. International Journal for the Scholarship of Teaching \& Learning, 4(2), 1-16. https://doi.org/10.20429/ijsotl.2010.040209

Harmsen, J. (2007). Measuring Bioavailability: From a Scientific Approach to Standard Methods. Journal of Environment Quality, 36(5), 1420. https://doi.org/10.2134/jeq2006.0492

Insyasiska, Zubaidah, D. S., \& Susilo, H. (2015). Pengaruh project based learning terhadap motivasi belajar, kreativitas, kemampuan berpikir kritis. Jurnal Pendidikan Biologi Volume, 7(1), 9-21.

Jensen, J. L., \& Lawson, A. (2011). Effects of Collaborative Group Composition and Inquiry Instruction on Reasoning Gains and Achievement in Undergraduate Biology. Cell Biology Education, 10(1), 64-73. https://doi.org/10.1187/cbe.1007-0089

Machin, A. (2013). Implementasi Pendekatan Saintifik, Penanaman Karakter Dan Konservasi Pada Pembelajaran Materi Pertumbuhan. Jurnal Pendidikan IPA Indonesia, 2(2), 203-208. https://doi.org/journal.unnes.ac.id/nju/index.php/jpii

Marjan, J., Arnyana, I. B. P., \& Setiawan, I. G. a N. (2014). Pengaruh Pembelajaran Pendekatan Saintifik Terhadap Hasil Belajar Biologi dan Keterampilan Proses Sains Siswa MA Mu' allimat NW Pancor Selong Kabupaten Lombok Timur Nusa Tenggara Barat. Jurnal Pendidikan IPA, 4(1), 1-12. Retrieved from 
http://pasca.undiksha.ac.id/e-ournal/index.php/jurnal_ipa/article/view/1316/1017

Noviar, D., \& Hastuti, D. W. I. R. (2015). Pengaruh Model Problem Based Learning (PBL) Berbasis Scientific Approach terhadap Hasil Belajar Biologi Siswa Kelas X di SMA N 2 Banguntapan T . A . 2014 / 2015, 8, 42-47.

Paulo, J., \& Cruz, C. (2015). Development of an Experimental Science Module to Improve Middle School Students ' Integrated Science Process Skills. DLSU Research Congress 2015, 3, 1-6.

Pratiwi, H. E., Suwono, H., \& Handayani, N. (2013). Pengembangan Modul Pembelajaran Biologi Berbasis Hybrid Learning Untuk Meningkatkan Kemampuan Berpikir Kritis Dan Hasil Belajar Siswa Kelas XI, 1-12.

Tan, S. Y., \& Halili, S. H. (2015). Effective Teaching of Higher-Order Thinking (HOT) in Education. The Online Journal of Distance Education and E-Learning, 3(2), $41-47$.

Wenno, I. H. (2010). Pengembangan Model Modul IPA Berbasis Problem Solving Method Berdasarkan Karakteristik Siswa Dalam Pembelajaran di SMP/Mts. Cakrawala Pendidikan2, 29(2), 176-188.

Yerimadesi, Putra, A., \& Ririanti. (2017). Efektivitas Penggunaan Modul Larutan Penyangga Berbasis Discovery Learning Terhadap Hasil Belajar Siswa Kelas XI MIA SMAN 7 Padang. Jurnal Eksakta Pendidikan (JEP), 1(1). 